(Salkoaski)...... On arometic substances in the animal body, and determination of sulphuric acid in urine (Baumann).-On animal and plant albuminous bodies (Weyl). - On lactosuria (Hofmeister); and on the physiology of lactic acid (Spiro). The journal is a decided acquisition to scientific literature.

WE have raceived the progxamme of excursions of the Manchester Field Naturalists' and Archæologists' Society for July to October. The seven excursions arranged (for Saturdays) appear to be of a varied and interesting character.

THE additions to the Zoological Society's Gardens during the past week include an Egyptian Gazelle (Gazellat dorcas) from North Africa, presented by Mr. H. B. Benson; a Malbrouck Monkey (Cercopithecus cynosurus) from West Africa, presented by Mrs. Escott; a Burmeister's Cariama (Chunga burmeisieri), a Brazilian Stilt Plover (Himantopus brasiliensis) from Buenos Ayres, two Black Swans (Cyguns atratus) from Australia, two Piping Guans (Pipile cunanznsis) from Bahia, an Urumutum Curassow (Nothocrax thumutnm) from Brazil, deposited; a Wapiti Deer (Cervus canaderisis), an Indian Muntjac (Cervulus Mazntjac) born in the Gardens.

\section{ASTRONOMTCALSYMBOLISM OF THE EAST}

$T \mathrm{Fi}$ two stars which in the book of Job are connected with Orion, and to which the Indian Orion-legend referred, are conrected with the two red stars or Rohini of Indian traditions. It is shown that these two fixed stars, observed as contemporaneously rising and setting on the horizon, formed the unchangeable starting points for regulating the lunations, and that they thus brought about in course of time an absolute correct chronology. The early discovery of equinoctial precession led to the substitution of these fixed stars by the changeable ecuninoctial points, till Copernicus, by separating the latter from the solar path, re-established the correct measurement of time by referring the solar motion to fixed stars. The determining sing le stars, later, constellations nearest to the equinoctical points, to which former, both Chinese and. Persian, traditions refer, became the symbol of the order manifested by the heavenly borties, which cosmical order was attributed to the Deity. The spmbol of the two cherubs or kirubs, that is "bulls," in the lwigutage of cuneiform insciptions, are shown to have referred to the rising and setting of the constellation of Taurus, which being called Kirub at its rising, was called Seraph, or Ser-Apis, iicerally, "the grave of the bull," at its setting. The Pleiades in the neck of Taurus stand in the same relation to this constellation as the god Sebaot; the god of the Sheba-ut, or severt stars, the Sibut of the Babylonians, to the Cherub. The symbol of the chariot of the Cherubim, and of Jehovah riding on the Cherub, as the Pleiades may be said to be riding on Taurus, are thus astronouically explained, and connected with the representations of Ormuzd riding on the winged bull, as also with similar Mithraic representations. The fortnightly period of the Hebrews, from the new moon to the full moon, in connection with the precessional cycle of seventy-two years, probably known to the Hebrews, is shown to have formed the tusis of the Osiris-Typhon legend, which was fully developed before the commencement of Egyptian history. The fourteen divisions of the litanies of Thot, the god riding on the moon, and whose secret number was seventy.two, are explained by reference to fourteen moon-stations of the lunar zodiac, the hidden Mazzaroth or mansions of the moon in the book of Job, and to the precessional cycle of seventyntwo years, with which can be cormected the solar year and the Phonix period of the Egyptians, the Saros of the Babylonians, and the Mosaic period of one day like a thousand years, as well as several other Babylonian periods; also the number of the sons of Japhet, and the genealogies in Luke from Seth to Joseph, the husband of Mary. When the solar zodiac had taken the place of the lunar zodiac, when the two determining fixed stars had been replaced by the changeable equinoctical points, and the commencement of spring and of autumn became the fundamental symbol of all religions, the ideal heroes of light "were connected with the spring-equinox, at first in Taurts, and the ideal heroes of

I Abstract of paper read at the Society of Biblical Archroology, "On Astronomical Symbolism of the East, as transmitted, by Hebrev's and Christians," by M. Ernest de Bunsen. darkness with the autumn-equinox, at first in Scorpio, close to which is the constellation of the Serpent. Thus to Ormuzd, Indra, Osiris, Dionysos and Apollos, were respectively opposed the serpent deities Ahriman, Ahi, Typhon, the Titans and Python. So also the Messiab, "The Sun of Righteousness," and "the day-spring from on high," was opposed by Satan, literally the antagonist, "the old serpent" the devil. The transition from the sacrifice of bulls to the sacrifice of lambs, and the vicarious and sin-removing character of these sacrifices in pre-Abrahamic times, is shown to have been connected with, and probably to have been caused by equinoctial precession, by Aries having taken the place of Taurus. Some of the mysteries of the Great Pyramid are explained by Eastern astronomical symbolism and the two passages pointing north and south are shown probably to have referred to the approximatively contem. poraneous midnightly culminations of Aldebaran and Antares at the autumn equinox, as observable at places in the latitude of the Great Pyramid, and likewise in the latitudes of Bactria and Northern India, during a period of about 150 years, within which the year 3300 B.C. falls. The fact that Chinese, Indians, and Arabians, at a remote period, comted twenty-eight moon stations, but that there is nowhere a trace of twenty-nine mansions of the moon, is submitted as possibly implying a date for the earliest astronomical observations of the East transmitted to us, at a time when the lunar month, now having a duration of about twenty-nine and a half days have only twenty-eight days, or rather, not yet twenty-nine. As the mean motion of the moon is the same in long periods, this period of twenty.nine days would have probably commenced about 600,000 years ago, if the retardation of the earth's rotatory motion, by which alone the prolongation of the linar month seems to be explainable, really does amount to twenty two seconds in a century, as now asserted by high authorities.

\section{THE NORWEGTAN EXPEDITION TO THE NORTH SEA}

FROM a letter by Prof. G. O. Sars, in the Christiania Dagbladet, dated Bodö, June 24, we make the following quotations with reference to the progress of the Norwegian expedition which left Bergen on June $x \mathrm{I}$ :-

"On the I 6 th of June we had arrived sufficiently far northward to commence our labours, and sounding-lines, thermometers, dredges, and trawling-nets were at once called into use. Since then the work has been pursued unremittingly, despite stormy wethther, and we have every reason to be satisfied with the results so far. The hitherto-inknown contour of the sea's bottom between Folden fiord and the Lofoten Islands is now so clearly ascertained by means of our transverse section, that we can map out to the north with a certain degree of precision the curve of the extended barrier, which keeps back the cold water coming from the depths of the Polar Sea. We have found the curve somewhat different from our expectations, especially in the neighbutrhood of the Lofoten. The soundings appear to indicate the presence of a remarkable indentation, similar to the one on the southern part of the coast, and we have found a precipitous slope of the sandbank resembling that of the well. known "Storeg" near Aalesund. It is evident that we have encountered here a most irmportant submarine conformation. The consideration of its effect on our sea-fisheries will be delayed until more detailed surveys have been carried out. In the course of our soundings on the way to Bodö, we were able-by means of the improved Negretti-Zambra thermometer to establish beyond the range of doubt the presence of a layer of warm water below a layer of cold water of considerable depth.

"Our zoological acquisitions have been highly satisfactory, especially those in the cold zone. We have added several species to the list of the previous expeaition; amongst them some hitherto detected in the Polar Sea only and others entirely new.

"The voyage will be pursued to Röst, where several days will be spent in magnetic observations, and in gathering zoological specimens. The latter promise to be of value on account of the zoographical interest of the locality, which has as yet been left unvisited. The section from Röst will be followed carefully in order to determine with certainty the expected bend in the sandbank. The progress of our expedition shows us more and more the fundamental importance of an accurate knowledge of the physical nature of the North Sea, not only for Norway, but also for the solution of the general questions with regard to the physical and biological conditions of the ocean in general," 